\title{
Pochodzenie synagogi
}

Świątynia w Jerozolimie nie była jedynym miejscem, gdzie wyznawcy Boga Przymierza wyznawali i uwielbiali Go po powrocie z deportacji w Babilonii w okresie tzw. Drugiej Świątyni. Temu celowi służyły też synagogi. Termin synagoga ( $\sigma u v \alpha \gamma \omega \gamma \eta ́)$ oznacza „zgromadzenie”. Pochodzenie bardzo stabilnej instytucji Synagogi - jak ją określa S. Safrai - jest ciągle przedmiotem badań. Jak przedstawia się w literaturze stan badań nad tą kwestią i jak można odnieść się do owego status questionis? Istotnym zagadnieniem są przy tym klarowne rozróżnienia terminologiczne w odniesieniu do Synagogi jako instytucji i synagog jako miejsc sakralno-społecznych.

Jedne opinie, zwłaszcza starsze, głównie uczonych żydowskich, chcą widzieć jej instytucjonalne umocowanie już w czasach reformy prowadzonej przez Jozjasza ${ }^{3}$. Stamtąd forma ta miałaby być przeniesiona

${ }^{1}$ Septuaginta tak tłumaczy hebr. qāhāl; o terminologii dotyczącej synagogi zob. Ancient Synagogues: Historical Analysis and Archaeological Discovery, ed. by D. Urman, P. V. C. Flesher, Leiden 1998, s. XIX; B. W. W. Dombrowski, Synagōgé in Acts 6:9, [w:] Intertestamental essays in honour of Józef Tadeusz Milik, ed. by Z. J. Kapera, Kraków 1992, s. 54-56 (Qumranica Mogilanensia, 6); zob. S. Kraus, Synagogale Altertümer, Berlin-Wien 1922, s. 2-102.

${ }^{2}$ Zob. S. Safrai, Synagogue, [w:] The Jewish People in the First Century: Historical Geography, Political History, Social, Cultural and Religious Life and Institutions, t. 1, ed. by S. Safrai, M. Stern, D. Flusser, Assen 1976, s. 908; C. Claussen, Versammlung, Gemeinde, Synagoge. Das hellenistisch-jüdische Umfeld der frühchristlichen Gemeinden, Göttingen 2002, s. 153; dla ortodoksyjnych rabinów instytucja synagogi zakorzeniona jest w osobie i czasach Mojżesza - zob. H. L. Strack, P. Billerbeck, Kommentar zum Neuen Testament aus Talmud und Midrash, München 1926, t. 2, s. 740; szeroki przegląd opinii zob. w L. I. Levine, The Ancient Synagogue: The First Thousand Years, New Haven-London 2000.

${ }^{3}$ Zob. J. Weingreen, The Origin of the Synagogue, „Hermathena” 98 (1964), s. 68-84. 
i rozwijana $\mathrm{w}$ środowisku deportacyjnym w Babilonii ${ }^{4}$, potem zunifikowana z odbudowaną świątynią w Jerozolimie poprzez umieszczenie w niej przyniesionych przez repatriantów z Babilonii zwojów Tory ${ }^{5}$. Być może pogląd taki miał wyrazić przekonanie o ciągłości Pierwszej i Drugiej Świątyni w Jerozolimie. Inni przesuwają jej powstanie na czasy reformy prowadzonej przez Ezdrasza i Nehemiasza ${ }^{6}$. Niektórzy początki Synagogi chcą widzieć dopiero w III wieku przed Chrystusem w diasporze w Egipcie ${ }^{7}$. Pojawily się też sugestie, że o powstaniu Synagogi można mówić dopiero po sukcesie powstania Machabeuszy z pewnością przed I wiekiem przed Chrystusem ${ }^{8}$. L. I. Levine prezentuje pogląd, że starożytna instytucja synagogi wynurzyła się jako odrębna od innych instytucja w Palestynie i w diasporze dopiero w okresie hellenistycznym? Skrajne, jak się wydaje, opinie chcą widzieć synagogę jako faryzejską, ekskluzywistyczną instytucję szkolną, której cechą charakterystyczną była wewnętrzna solidarność związków synagogalnych.

Nie brak też opinii, że niepodobna jednoznacznie ustalić genezy instytucji synagogi, ponieważ niezwykle trudną kwestią jest określenie czasu zaistnienia synagogi jako miejsca zebrań kultycznych i szkolnych

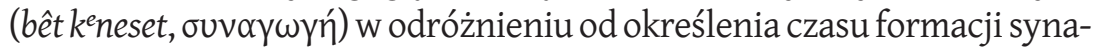
gogi jako instytucji religijnej i społecznej. W publikacjach traktujących o zjawisku synagogi ujawnia się bardzo mocno tendencja racjonalizująca, która miałaby być istotnym kryterium weryfikacji hipotez o jej pochodzeniu. Jest nią porównawczy materiał archeologiczny. Jednakże

${ }^{4}$ Zob. M. Weinfeld, Deuteronomy and the Deuteronomic School, Winona Lake 1992, s. 44: "conclude that it was Deuteronomy, or that Josianic reform, which paved the way for the institution of the synagogue".

${ }^{5}$ Tak podają niektóre teksty rabinackie, mówiąc o zbudowaniu synagogi w Nahardea z kamieni Pierwszej Świątyni przez króla Jehojakina (Sherira Ben Hanina z V wieku po Chrystusie, gaon akademii w Pumpedita) - zob. J. R. Branham, Vicarious Sacrality: Temple Space in Ancient Synagogues, [w:] Ancient Synagogues..., dz. cyt., s. 343.

${ }^{6}$ Zob. S. Safrai, Synagogue, [w:] The Jewish People in the First Century..., dz. cyt., s. 912.

${ }^{7}$ Zob. J. G. Griffiths, Egypt and the Rise of the Synagogue, [w:] Ancient Synagogues..., dz. cyt., s. 3-16; L. L. Grabbe, Synagogues in Pre 70-Palestine: a Re-assesment, [w:] Ancient Synagogues..., dz. cyt., s. 18-19.

${ }^{8}$ Zob. L. L. Grabbe, Synagogues in Pre 70-Palestine: a Re-assesment, [w:] Ancient Synagogues..., dz. cyt., s. 20-21.

${ }^{9}$ Zob. L. I. Levine, Judaism and Hellenism in Antiquity. Conflict Or Confluence, SeattleLondon 1998, s. 139. 
wartość tego materiału jest w tym przypadku względna. Dlaczego? Czy można mieć pewność, że dotychczasowe odkrycia archeologiczne ujawniły wszystkie dane? Jest to tylko aktualny stan badań archeologicznych i dotyczy raczej form architektonicznych i ograniczonych danych epigraficznych. Ponadto w literaturze przedmiotu znajdziemy stwierdzenia, że brak jest wystarczającego materiału z okresu końca Drugiej Świątyni i wczesnego rabinizmu. Pozostaje dość ogólne stwierdzenie, że judaizm $\mathrm{w}$ wymiarze lokalnym instytucjonalizował się $\mathrm{w}$ formie synagogalnej ${ }^{10}$.

Najliczniej prezentowany jest pogląd, głównie w publikacjach uczonych żydowskich, że początki zjawiska synagogi należy lokować w środowisku Judejczyków deportowanych do Babilonii po zburzeniu świątyni w 586 roku, a jej rozwój miałby miejsce w okresie Drugiej Świątyni ${ }^{11}$. Motywem była zapewne idea konsolidacji wygnańców wokół tradycyjnej formy przeżywania swej tożsamości, tzn. wokół kultu. Ponieważ niemożliwy był kult w dotychczasowej świątynnej formie, zainicjowano jego substytut, nowy model tożsamości możliwy do praktykowania w tamtych realiach. Dotychczasowe formy kultyczne, celebracje świąt i kult prywatny miały charakter ofiarniczy, koncentrujący się na przywoływaniu najważniejszych wydarzeń z historii Izraela. Jego kwintesencją była formacja Izraela jako ludu przymierza. Bez istnienia świątyni ta postać kultu była niemożliwa, stąd następowała koncentracja na memoryzacji historii i związanych z nią norm kultyczno-moralnych odnoszących się głównie do idei przymierza. Synagoga stawała się więc locus dla prezentacji przykazań Boga, aby je rozważać, egzegetować, komentować i w ten sposób zachować własną tożsamość' ${ }^{12}$.

${ }^{10}$ Zob. R. A. Horsley, Synagogues in Galilee and the Gospels, [w:] Evolution of the Synagogue. Problems and Progress, ed. by H. C. Kee, L. H. Cohick, Harrisburg 1999, s. 47.

${ }^{11}$ Przegląd opinii i literatury je prezentującej zob. w Ancient Synagogues..., dz. cyt., s. XX-XXIV. Brak jest jednak w literaturze szerszych opracowań przemawiających za prawdziwością tej hipotezy; nie podejmuje tej tematyki nawet obszerne współczesne dzieło: O. Lipschitz i J. Blenkinsopp, Judah and the Judeans in the Neo-Babylonian Period, Winona Lake 2003, ani też: O. Lipschitz, G. N. Knoppers, R. Albertz, Judah and the Judeans in the Fourth Century B. C. E., Winona Lake 2007.

${ }^{12}$ O liturgii synagogalnej i jej rozwoju zob. w L. I. Levine, The Development of Synagogue Liturgy in Late Antiquity, [w:] Galilee through the Centuries. Confluence of Cultures, Winona Lake 1999, s. 123-144. 
Niektórzy badacze prezentują opinię, że na podstawie tekstów biblijnych (Ezd 8, 17; Ez 11, 16) można też mówić o istnieniu w Babilonii alternatywnej formy żydowskiej świątyni ${ }^{13}$. Sugeruje się też, że w dia-

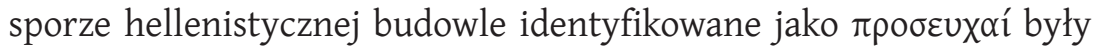
rozumiane i używane jako alternatywne ,świątynie” o charakterze substytucjonalnym, w których liturgia obejmowała te elementy kultyczne wzięte z tradycji świątynnej, które nie miały charakteru ofiarniczego. Taki bowiem model funkcjonował w różnych grupach etnicznych w Babilonii i w Egipcie, pośród których (i wespół z którymi) zamieszkiwała społeczność żydowska ${ }^{14}$.

W okresie Drugiej Świątyni aż do jej zburzenia w roku 70 świątynia wespół z instytucją synagogi stanowiły prawdziwe centrum duchowe judaizmu ${ }^{15}$. Świętość synagogi nie równała się naturalnie świętości świątyni, ale Józef Flawiusz stosuje do synagogi zakaz umieszczania w niej posągów, podkreślając w ten sposób świętość tej ostatniej. W Antiquitates pisze: „Wkrótce po tym młodzi ludzie w Dorze, stawiając zuchwałość ponad świętość i z natury skłonni do śmiałych i nierozważnych czynów, przynieśli posąg Cezara do synagogi i tam go umieścili”"16. Tak samo świętość synagogi traktuje Filon (Ad Flaccum, 48).

Występowała jednak między oboma instytucjami istotna dystynkcja zależna od regionu geograficznego. W tej kwestii Flesher twierdzi, że o ile w Galilei, gdzie wprowadzono ją wcześniej niż w Judei ${ }^{17}$, synagoga naturalizowała się, dystansującjak gdyby świątynię w Jerozolimie, o tyle w Judei instytucja Synagogi zawsze, co wydaje się zrozumiałe, pozostawała $\mathrm{w}$ cieniu świątyni ${ }^{18}$. Zjawisko synagogi $\mathrm{w}$ diasporze miało bardzo zróżnicowany charakter. Ponadto w odróżnieniu od świątyni

${ }^{13}$ Zob. P. R. Bedford, Temple Restoration in Early Achaemenid Judah, Leiden 2001, s. 49.

${ }^{14}$ Zob. L. E. Browne, Early Judaism, Cambridge 1929, s. 53.

${ }^{15}$ Zob. F. Schmidt, Pensamento do templo - De Jerusalém a Qumran, São Paulo 1998, s. 56; P. V. C. Flesher, Palestinian Synagogues before 70 C. E. A Review of the Evidence, [w:] Ancient Synagogues..., dz. cyt., s. 29.

${ }^{16}$ J. Flawiusz, Dawne dzieje Izraela. Antiquitates Judaicae, tł. Z. Kubiak, J. Radożycki, pod red. E. Dąbrowskiego, Poznań 1962, s. 929.

${ }^{17}$ Zob. O. Skarsaune, In the Shadow of the Temple. Jewish Influences on Early Christianity, Downers Grove 2002, s. 79.

${ }^{18}$ Zob. P. V. C. Flesher, Palestinian Synagogues before 70 C. E. A Review of the Evidence, [w:] Ancient Synagogues..., dz. cyt., s. 39. 
posiadało bardzo istotny przymiot. Był to jej wymiar uniwersalizujący, u podstaw którego stała idea modlitwy. Idea ta, rozbudowana i wielorako wyrażana, stała się substytutem działalności kultycznej świątyni w Jerozolimie po jej zburzeniu w roku 70. Neusner nazywa to „narodzinami judaizmu". Niewątpliwie Synagoga stanowiła istotny wymiar ówczesnego życia żydowskiego ${ }^{19}$.

W żydowskiej diasporze w Egipcie w III wieku przed Chrystusem sy-

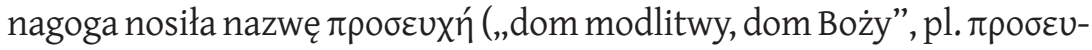

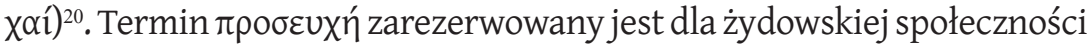
w diasporze, zwłaszcza egipskiej, jakkolwiek J. Flawiusz tak nazywa też

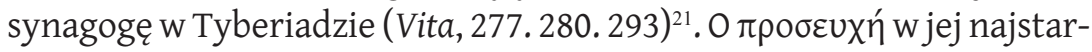
szej formie zaświadczają dwie egipskie inskrypcje z okresu Ptolemeusza III (246-221 przed Chrystusem) $)^{22}$. Jeden z papirusów greckich (z Arsinoe) na określenie miejsca modlitwy żydów z Arsinoe (w odróżnieniu

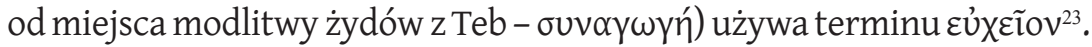
J. Mélèze-Modrzejewski przywołuje też grecką terminologię Rabbiego

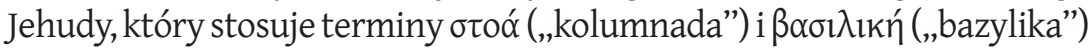
w opisie budynku synagogi ${ }^{24}$. Funkcja społeczno-kulturowa synagogi wyraża się w określeniu jej mianem ả $\mu \varphi \imath \theta \varepsilon ́ \alpha \tau \rho o v$. W I wieku naszej ery

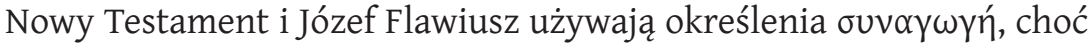
Flawiusz w Antiquitates, 14, 245-246; 16, 164 synagogę określa też jako

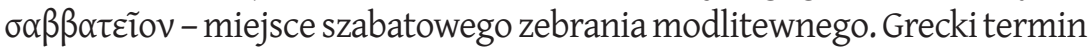
iعрóv (,świątynia” lub „święte miejsce”) używane w kontekście synagogi

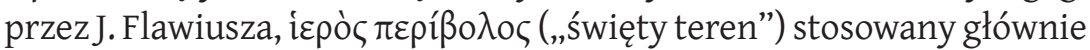
przez Filona i obecny w inskrypcjach w Egipcie świadczą o sakralnej

${ }^{19}$ L. I. Levine, Judaism and Hellenism in Antiquity..., dz. cyt., s. 31, wymienia synagoge, Jerozolimę i kulturę faryzejsko-rabiniczną jako trzy najistotniejsze wymiary żydowskiego życia w starożytności; zob. też L. L. Grabbe, Scribes and Synagogues, [w:] The Oxford Handbook of Biblical Studies, ed. by J. W. Rogerson, J. Lieu, Oxford 2006, s. 367.

${ }^{20}$ Omówienie proseuche zob. w C. Claussen, Versammlung, Gemeinde, Synagoge..., dz. cyt., s. 114-119.

${ }^{21}$ Zob. tamże, s. 117.

${ }^{22}$ Zob. The Cambridge history of Judaism, ed. by W. Horbury, W. D. Davies, J. Sturdy, t. 3: The Early Roman Period, Cambridge 1999, s. 77.

${ }^{23}$ Zob. J. Mélèze-Modrzejewski, Żydzi nad Nilem. Od Ramzesa II do Hadriana, Kraków 2000, s. 120-121; C. Claussen, Versammlung, Gemeinde, Synagoge..., dz. cyt., s. 132.

${ }^{24}$ Zob. J. Mélèze-Modrzejewski, Żydzi nad Nilem..., dz. cyt., s. 121. 
naturze starożytnej synagogi w diasporze dystansującej się od innych podobnych struktur nie-żydowskich ${ }^{25}$. Пع Flaccum (47-49) wydaje się mieć znaczenie miejsca dziękczynienia bądź modlitwy dziękczynnej. Dokumenty z Krokodilopolis tę część miasta,

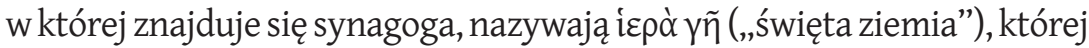
specjalny status gwarantowało hellenistyczne prawo w Egipcie ${ }^{26}$. Teren

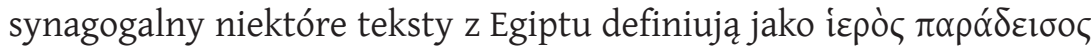
(,święty ogród”) 27 . O szkolnym charakterze świadczy termin $\delta 1 \delta \alpha \sigma k \alpha-$

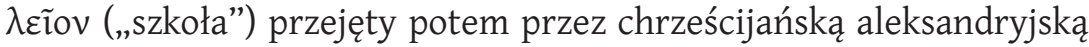
szkołę katechetyczną i wspólnoty kościelne w Egipcie. Mówi się także o funkcji nauczyciela dzieci w synagodze. Taka szkolna działalność synagogi jest jednak wtórna i raczej ma charakter społeczny, nawiązujący do prywatnych kolegiów w Imperium Rzymskim. Synagoga palestyńska to w okresie Drugiej Świątyni w Judei i Galilei nade wszystko miejsce targumicznego zastosowania świętych tekstów, szczególnie Prawa - najpierw ustne (charakter liturgiczny), potem literackie (środowisko szkolne $)^{28}$. Taką targumiczną funkcję pełniła także od III wieku przed

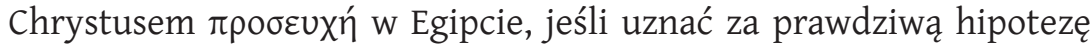
o istnieniu targumów greckich, wśród nich Septuaginty ${ }^{29}$.Jak pokazują teksty Ezd i Ne, w okresie perskim lektura i interpretacja Prawa była podporządkowana zasadom działalności perskiego imperium. Dlatego

${ }^{25}$ Zob. A. Kasher, The Jews in Hellenistic and Roman Egypt. The Struggle for Equal Rights, Tübingen 1985, s. 106-107. Wydaje się, że wyjaśnienia wymagałoby stwierdzenie o dedykacji synagog władcom ptolemejskim sformułowane przez P. Piwowarczyka, Żydzi egipscy wobec władców ptolomejskich. Rekonesans źródłowy, „Studia Judaica” 10 (2007) nr 2 (20), s. 220: „To im dedykowano synagogi”. Inskrypcja ze Schedia z III wieku przed Chrystusem zawiera co prawda stwierdzenie o dedykacji synagogi, ale akt ten można rozumieć raczej w kategoriach interesowności i korzyści zeń płynących niż lojalności wobec władcy. Można go przyrównać do jednej z możliwych, ale bardzo prawdopodobnych motywacji powstania przekładu Septuaginty. Chodzi o konieczność posiadania własnego zbioru prawnego dla korzystnego funkcjonowania żydowskiej społeczności, ale i dla własnej autonomii i odrębnej etyki, o czym pisze przywoływany przez P. Piwowarczyka J. Mélèze-Modrzejewski - zob. S. Jędrzejewski, Biblia i judaizm, Kraków 2007, s. 16-17.

${ }^{26}$ Zob. A. Kasher, The Jews in Hellenistic and Roman Egypt..., dz. cyt., s. 141.

${ }^{27}$ Zob. tamże, s. 138.

${ }^{28}$ Zob. L. L. Grabbe, Judaic Religion in the Second Temple Period. Belief and Practice from the Exile to Yavneh, London 2000, s. 164.

${ }^{29}$ Zob. S. Jędrzejewski, Biblia i judaizm, dz. cyt., s. 20-21. 
między innymi do Judy przybywa wraz z deportowanymi Ezdrasz z misją zbadania stosunków w Judzie i w Jerozolimie na podstawie Prawa

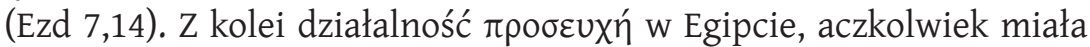
daleko idącą autonomię, musiała pozostawać w odpowiedniej korelacji do wymogów państwa ptolomejskiego.

Pewne fragmenty z Qumran (Dokument Damasceński, A XI, 21-22; XII, 1) mówiące o "domu pokuty (prostracji)" (bêt hištahăâôt) interpretowane są jako miejsce kultyczne, miejsce modlitwy ${ }^{30}$. Jeśli taka interpretacja byłaby prawdziwa - a ma ona wsparcie we wzmiance u Filona z Aleksandrii - mielibyśmy do czynienia z judaistyczną synagogą, inną niż te, które znane są ze źródeł biblijnych i greckich. Jeśli uwzględnić także działalność synagog samarytańskich, zróżnicowanie zjawiska synagogi w starożytności jeszcze wzrasta ${ }^{31}$. Uwzględnić też należy poświadczone przez Filona (De Vita Contemplativa, 25. 32. 89) funkcjonowanie miejsc kultycznych egipskich grup terapeutów nazywanych potrójnym określe-

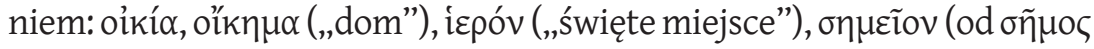
- „błyszczący, promieniujący”) ${ }^{32}$. Euzebiusz z Cezarei dodaje w odniesie-

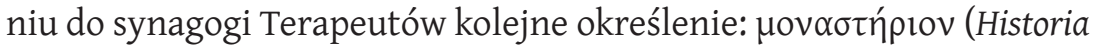
ecclesiastica, 2, 17. 9). Dość zasadniczą kwestią jest więc stwierdzenie, że określenie „synagoga” jest bardzo pojemne i odnosi się zarówno do materialnej przestrzeni sakralno-społecznej, pedagogicznej i politycznej, jak też do instytucjonalnego zjawiska religijnego i socjalnego.

W okresie Drugiej Świątyni wpływy kulturowo-religijne środowisk judzkich miały różny zasięg i natężenie. Z uwagi na wspólnotę języka aramejskiego i hebrajskiego używanych obok greckiego w synagogach były one większe w Syrii. To samo kryterium (tylko język grecki) czyniło je znacznie mniejszymi w Egipcie. $Z$ tego powodu organizacja synagogalna w różnych regionach mogła być zróżnicowana. Takie różnice potwierdzają badania w stosunku do synagogi w Aleksandrii i licznych

${ }^{30}$ Zob. A. Steudel, The Houses of Prostration CD XI, 21-XII, 1-Duplicates of the Temple (1), „Revue Qumran” 16 (1993), s. 49-68.

${ }^{31}$ Zob. R. Pummer, Samaritan Synagogues and Jewish Synagogues, [w:] Jews, Christians and Polytheists in the Ancient Synagogue. Cultural Interaction During the Greco-Roman Period, ed. by S. Fine, London 1999, s. 118-119.

${ }^{32}$ Zob. C. Claussen, Versammlung, Gemeinde, Synagoge..., dz. cyt., s. 143. 
synagog w egipskim chora. Samo zjawisko synagogi w jego szerokim rozumieniu niepodobna traktować $\mathrm{w}$ diasporze jednolicie ${ }^{33}$.

Organizacja struktury instytucjonalnej Synagogi przed rokiem 70 znana jest z tekstów biblijnych, głównie Nowego Testamentu, oraz z pism Józefa Flawiusza i Filona. Starotestamentalni mędrzec, kapłan i poeta stanęli u podstaw urzędów i funkcji synagogalnych ${ }^{34}$. Funkcja świątyni i synagogi w tym czasie miała pewien element wspólny, o którym świadczy wyznanie Jezusa: „Uczyłem zawsze w synagodze i w świątyni, gdzie się gromadzą wszyscy Żydzi" (J 18, 20). Znajdujemy w synagodze funkcję åpxlouvó $ү \omega \gamma o \varsigma$ - przełożonego synagogi utrzymywanego przez gminę (Łk 13, 14), który w diasporze żydowskiej w Egipcie był reprezentantem społeczności ${ }^{35}$. W tej kwestii reprezentatywna jest inskrypcja grecka Teodotusa z I wieku po Chrystusie znaleziona na Ofelu w Jerozolimie w 1913 roku: "Theodotus, syn Vettanosa, kapłan i archisynagogos, syn i wnuk archisynagogosa, zbudował synagogę, aby studiować przykazania" ${ }^{36}$.

Zapewne zarząd synagogi miał też charakter zbiorowy, ponieważ

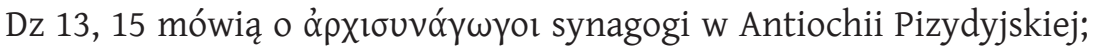
taki zarząd raczej miałby charakter prestiżowy. Regionalni przywódcy synagogalni spotykali się zapewne okolicznościowo w Jerozolimie, szczególnie przy okazji dorocznych uroczystości świątynnych (Dz 6, 9).

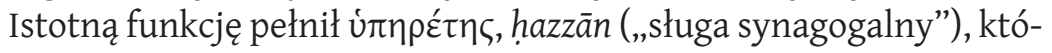
ry mógł pełnić różne role: czytać modlitwy, recytować psalmy i pieśni oraz wygłaszać komentarze. Jemu była powierzona funkcja strażnika ksiąg (zwojów). Być może posługiwał też jako dozorca synagogi i był utrzymywany ze zbiórek społecznych. Greckim odpowiednikiem sta-

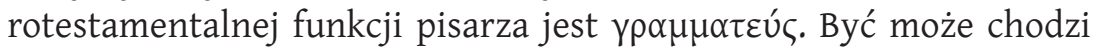
tutaj o jakąś funkcję administracyjną w synagodze, np. sekretarza. Inne

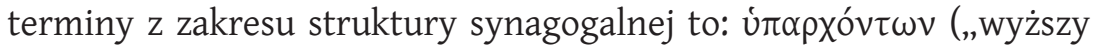

${ }^{33}$ Zob. A. T. Kraabel, Unity and Diversity among Diaspora Synagogues, [w:] The Synagogue in Late Antiquity, ed. by L. I. Levine, Philadelphia 1987, s. 49-60.

${ }^{34}$ Zob. M. D. Schwartz, Sage, Priest and Poet. Typologies of religious leadership in the Ancient Synagogue, [w:] Jews, Christians and Polytheists in the Ancient Synagogue..., dz. cyt., s. $101-117$.

${ }^{35}$ Zob. T. Rayak, D. Noy, Archisynagogoi: Office, Title and Social Status in the Greco-Jewish Synagogue, "Journal of Roman Studies" 83 (1993), s. 75-93.

${ }^{36}$ Adolph Deissmann, Light from the Ancient East Or the New Testament Illustrated by Recently Discovered Texts of the Graeco Roman Word, Whitefish 2003, s. 439-440. 


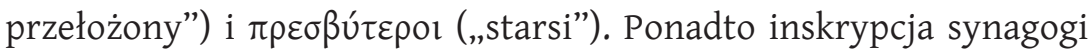
w Sardes zawiera określenie oo „przekazujący Torę"). Honorowymi tytułami wydają się być określenia „ojciec" i „matka” synagogi. Terminologia ${ }^{37}$ i struktura organizacji synagogi wskazuje na kilka funkcji, które wypełniała: religijną, edukacyjną, administracyjną, prawną i społecznąa

Późniejsza literatura rabiniczna używa określeń: aram. bêt k ${ }^{e} n i s ̌ t a ̄ '$ („dom zgromadzenia”), hebr. bêt hā'ām („dom ludu”), aram. 'atrā'

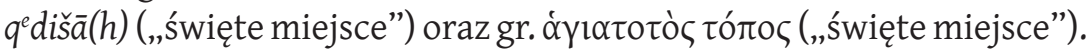
Badania wskazują na istotny wpływ rabinów na działalność synagog po powstaniu Bar Kochby ${ }^{39}$. Rozwój instytucji synagogalnej w okresie rabinicznym charakteryzuje się daleko idącym spolaryzowaniem jej form architektonicznych, zakresu działalności i struktury ${ }^{40}$.

Poszukiwania początków instytucji Synagogi i obraz późniejszego jej rozwoju powinny uwzględniać podstawowe jej funkcje widoczne i określone w wyniku badań, m.in. archeologicznych. Albowiem zarówno formy konstrukcyjne synagog, jak też ich instytucjonalne i pragmatyczne funkcje zależne były od dwóch czynników: czasu i miejsca. Funkcją najlepiej poznaną jest działalność liturgiczna z zasadniczym jej elementem, czyli uroczystą lekturą Tory, jej wykładem oraz modlitwą ${ }^{41}$. Synagoga jawi się w ten sposób jako „sanktuarium Tory”. Prace archeologiczne zidentyfikowały też w niektórych synagogach miejsca do rytualnych

${ }^{37}$ Przegląd terminologiczny hebrajski, grecki i aramejski zob. The Cambridge history of Judaism, dz. cyt., t. 3, s. 268-270.

${ }^{38}$ Zob. The Cambridge history of Judaism, dz. cyt., t. 3, s. 77; S. Safrai, Synagogue, [w:] The Jewish People in the First Century..., dz. cyt., s. 942-943.

${ }^{39}$ Zob. J. Neusner, A. J. Avery-Peck, Judaism in Late Antiquity: Where We Stand:Issues and Debates in Ancient Judaism, Leiden 1998, s. 175; jednostronne stanowisko o przemożnej, rabinackiej formie wykorzystywania synagogi tylko do recytacji Tory w liturgii krytykuje J. F. Strange, The Synagogue as Metaphor, [w:] Judaism in late antiquity, red. J. Neusner, B. Spuler, H. R. Idris, Leiden 2001, s. 93.

${ }^{40}$ Zob. S. S. Miller, The Rabbis and the non-existent monolithic Synagogue, [w:] Jews, Christians and Polytheists in the Ancient Synagogue..., dz. cyt., s. 50-61; o liturgii synagogalnej zob. w S. K. Reif, The Early Liturgy of the Synagogue, [w:] The Cambridge History of Judaism, dz. cyt., t. 3, s. 326-357; opracowanie literatury synagogalnej z okresu Miszny i Talmudu, szczególnie dotyczącej szabatu i świąt, zob. w J. Heinemann, J. Petuchowski, Literature of the Synagogue, New York 2006.

${ }^{41}$ Zob. S. Safrai, Synagogue, [w:] The Jewish People in the First Century..., dz. cyt., s. 915. 
oczyszczeń. Trudno powiedzieć, jakie istotnie miały one znaczenie, ale sądzić można, że mogły one wiązać się z kultem ${ }^{42}$. Funkcje nieliturgiczne synagogi to działalność socjalna, szkolna i sądownicza w zależności od warunków i potrzeb lokalnych. Rolą synagogi było również zarządzanie społecznością żydowską. Pełniła w ten sposób funkcję ośrodka dbającego o tożsamość narodową i religijną ${ }^{43}$. Synagoga miała nie tylko znaczenie religijne i społeczne, ale także polityczne. O ile w Jerozolimie działalność taka była zapewne zminimalizowana i z uwagi na świątynię koncentrowała się na płaszczyźnie społecznej, o tyle na pozostałym terenie - zwłaszcza w diasporze - rola ta była istotna. Nie bez znaczenia była zapewne także funkcja konsolidująca lokalne społeczności żydowskie zarówno w oficjalnej, publicznej działalności synagogi, jak i poprzez działania mniej formalne. W pierwotnych gminach chrześcijańskich, szczególnie związanych z działalnością św. Pawła, synagogę widzimy jako naturalne środowisko ewangelizacji Apostoła Narodów ${ }^{44}$. Pierwotna organizacja Kościoła wzorowała się bowiem na strukturze synagogalnej. Na tych płaszczyznach należy szukać odpowiedzi na pytania o początki, rozwój i zróżnicowanie samej instytucji Synagogi, jak i synagog pojmowanych w całym bogactwie swych funkcji.

Kraków

SYLWESTER JĘDRZEJEWSKI SDB

\section{Słowa kluczowe}

Synagoga, funkcje, judaizm, deportacja, Babilon, Egipt, diaspora

${ }^{42}$ Zob. L. L. Grabbe, Judaic Religion in the Second Temple Period..., dz. cyt., s. 139-140.

${ }^{43}$ Zob. H. C. Kee, Deffining the First-Century C. E. Synagogue, [w:] Evolution of the Synagogue..., dz. cyt., s. 7-8; G. Reeg, Synagogue, [w:] The Encyclopedia of Christianity, t. 5, editors E. Fahlbusch [i in.], Grand Rapids-Leiden 2008, s. 265.

${ }^{44}$ Zob. J. T. Burtchaell, From Synagogue to Church. Public Services and Offices in the Earliest Christian Communities, New York-Cambridge 1992; J. J. Collins, Between Athens and Jerusalem. Jewish Identity in the Hellenistic Diaspora, Grand Rapids $2000^{2}$, s. 264-270. 


\section{Summary}

\section{The origin of the synagogue}

The institution of Synagogue and the synagogue as the local zone of Jewish activities served three basic functions: socio-cultural, religious and educational. The origins of the Synagogue is dated differently depending on research environment: from reforms of Josiah till the Hasmonean period. Extreme opinions represent the pessimistic approach concluding that this is impossible to clearly establish the genesis of the institution of the Synagogue. The synagogue was born in the deportation environment of Babylonia with the main goal of preserving the ethnic and religious identity. It had liturgical, social, juridical and educative functions. It developed quickly in the Egyptian Diaspora during the Ptolemaic period and during the Roman rule. In Palestine the development was different. Institutional capacity of the Synagogue was realized in the activities of local synagogues in sacral, social, pedagogical and political context.

\section{Keywords}

Synagogue, functions, Judaism, deportation, Babylon, Egypt, diaspora 


\section{Wydawnictwo astraía poleca nową książkę}

\section{ArCHiteKTURA I LITURGIA}

Pierwsze tłumaczenie doskonałej książki Louisa Bouyera o powiązaniu architektury z liturgią pozwoli dostrzec ciągłość stylu świątyni od judaizmu do XX wieku oraz wzajemne przenikanie się i konieczność uzupełniania się architektury i liturgii.

www.astraia.pl

Zamówienia i informacje: tel./faks (12) 65495 86, e-mail: astraia@astraia.pl 